\title{
Retinal nerve fibre layer thickness measured by spectral domain optical coherence tomography amongst early primary open-angle glaucoma patients at Hospital Melaka
}

Anhar Hafiz Silim ${ }^{1,2}$, Raja Norliza Raja Omar ${ }^{1}$, Othmaliza Othman², Rona Asnida Nasaruddin², Norshamsiah Md Din ${ }^{2}$

${ }^{1}$ Department of Ophthalmology, Hospital Melaka, Melaka, Malaysia; ${ }^{2}$ Department of Ophthalmology, Hospital Canselor Tuanku Muhriz, Universiti Kebangsaan Malaysia Medical Centre (UKMMC), Cheras, Kuala Lumpur, Malaysia

\section{Abstract}

Introduction: Glaucoma is second only to cataract as a cause of blindness worldwide and Asians account for almost half the cases. Retinal nerve fibre layer (RNFL) assessment is an important objective method for diagnosis and monitoring of glaucoma as it develops earlier than the development of visual field defects.

Purpose: To estimate the proportion of primary open-angle glaucoma (POAG) patients with normal RNFL thickness (RNFLT) amongst early POAG patients who were under follow-up at the Ophthalmology Department, Hospital Melaka (Melaka, Malaysia).

Study design: Observational cross-sectional study.

Materials and methods: Consecutive sampling of 64 POAG patients who were diagnosed as early POAG as defined by the Glaucoma Staging System 2 (GSS 2) into stage 1 and 2 on Octopus visual field test were recruited in this study. Data collected included demographic data, refraction, slit-lamp examination, intraocular pressure (IOP), gonioscopy, peripapillary retinal nerve fibre layer thickness (RNFLT)

Correspondence: Norshamsiah Md Din, Department of Ophthalmology, Pusat Perubatan UKM, Jalan Yaacob Latif, 56000, Cheras, Kuala Lumpur, Malaysia.

E-mail: shamsiahdr@hotmail.com 
measured by spectral-domain optical coherence tomography (SD-OCT), and fundus photography.

Results: Among 64 eyes, $57.8 \%$ were found to have normal and $42.2 \%$ to have abnormal RNFLT classification. There was no difference in terms of age, gender or ethnicity between those with normal and abnormal RNFLT. Mean IOP at presentation, mean duration of POAG, and mean spherical dioptres were compared between the two groups. Only mean spherical dioptres showed a significant difference between the two groups, $p<0.001$. An increase of spherical dioptres also had a moderate positive correlation with RNFLT in most optic disc quadrants except the nasal, temporal, superonasal, and inferonasal quadrants.

Conclusion: OCT cannot be used as a diagnostic tool alone, especially in early glaucoma, as it showed a normal RNFLT in almost half the patients. RNFLT in early POAG had significant correlation with spherical dioptres in most quadrants.

Keywords: early primary open-angle glaucoma, optical coherence tomography, retinal nerve fibre layer thickness

\section{Pengukuran ketebalan lapisan serat saraf retina menggunakan tomografi koheren optik domain spektrum di kalangan pesakit glaukoma sudut terbuka primer peringkat awal di Hospital Melaka}

\section{Abstrak}

Pendahuluan: Glaukoma berada ditempat kedua selepas katarak sebagai penyebab kebutaan di seluruh dunia dan orang Asia menyumbang hampir separuh daripada kes ini. Penilaian ketebalan lapisan serat saraf retina (RNFLT) adalah kaedah objektif yang penting untuk diagnosa dan pemantauan glaukoma kerana perubahan ini berlaku lebih awal daripada pembentukan kecacatan medan penglihatan.

Tujuan: Untuk menganggarkan peratusan pesakit glaukoma sudut terbuka primer (POAG) peringkat awal dengan ketebalan RNFL normal di kalangan pesakit POAG di Jabatan Oftalmologi, Hospital Melaka (Melaka, Malaysia).

Reka bentuk kajian: Kajian pemerhatian keratan rentas.

Bahan dan kaedah: Persampelan berturut-turut telah dilakukan ke atas pesakit POAG. Seramai 64 pesakit yang didiagnosa sebagai POAG peringkat awal berdasarkan kepada skor ke atas ujian medan penglihatan Octopus menggunakan Glaucoma Staging System 2 (GSS 2) pada tahap 1 dan 2 telah direkrutkan dalam kajian ini. Data yang dikumpulkan termasuk data demografi, refraksi, pemeriksaan 
lampu slit, tekanan intraokular (IOP), gonioskopi, ketebalan lapisan serat saraf retina peripapillary (RNFLT) yang diukur dengan tomografi koheren optik-domain (SD-OCT), dan fotografi fundus.

Hasil: Di antara 64 mata yang terlibat, 57.8\% didapati mempunyai RNFLT normal dan $42.2 \%$ yang tidak normal. Tiada perbezaan dari segi umur, jantina atau etnik antara mereka yang mempunyai RNFLT normal dan tidak normal. Min IOP pada temujanji pertama, jangka masa purata POAG, dan min diopter sfera dibandingkan antara kedua-dua kumpulan. Hanya diopter sfera yang menunjukkan perbezaan yang signifikan antara kedua-dua kumpulan, $p<0.001$. Peningkatan diopter sfera juga mempunyai korelasi positif sederhana dengan RNFLT pada kebanyakan kuadran cakera optik kecuali kuadran nasal, temporal, superonasal, dan inferonasal. Kesimpulan: OCT sahaja tidak dapat digunakan sebagai alat diagnostik, terutama pada glaukoma peringkat awal. Ini adalah kerana RNFLT adalah normal pada hampir separuh pesakit yang terlibat. RNFLT pada peringkat awal POAG mempunyai hubungan yang signifikan dengan diopter sfera di kebanyakan kuadran.

Kata kunci: glaukoma sudut terbuka primer peringkat awal, ketebalan lapisan serat saraf retina, tomografi koheren optik

\section{Introduction}

Glaucoma is a neurodegenerative disease caused by progressive retinal ganglion cell (RGC) loss associated with characteristic structural changes in the optic nerve head and retinal nerve fibre layer (RNFL). The neural insult can result in functional loss and decrease in vision-related quality of life.

The prevalence of glaucoma in the world is increasing. Glaucoma is second only to cataract as a cause of blindness worldwide and Asians account for almost half the cases. ${ }^{1}$ It was estimated that in 2010, 60.5 million people had glaucoma worldwide, which will increase to 79.6 million by 2020 . Of this number, $74 \%$ will have open angle glaucoma (OAG) and 4.5 million people will suffer bilateral blindness. ${ }^{1}$ The probability of patients becoming blind from newly diagnosed and treated ocular hypertension or OAG at 20 -years follow-up was estimated to be $27 \%$ in one eye and $9 \%$ in both eyes. ${ }^{2}$

In two population-based studies in Singapore, Foster et al. and Shen etal. reported that the prevalence of glaucoma among the Chinese ${ }^{3}$ and Malay ${ }^{4}$ populations was $3.2 \%$ and 3.4\%, respectively, in those aged between 40 and 80 years old. Most of them were diagnosed with primary open-angle glaucoma (POAG). Data from our National Eye Survey in 1996 showed that the prevalence of blindness in Malaysia was $0.29 \%$, with glaucoma contributing to $1.8 \%$ of blindness. Other major causes of blindness were cataract (39.1\%), retinal disease (24.5\%), uncorrected refractive error (4.1\%), and corneal disease (3.4\%). ${ }^{5}$ 
In view of the increasing number of adult and elderly patients potentially diagnosed with glaucoma in the coming years, improved and aggressive diagnostic approaches, detection of progression, and estimation of deterioration in disease rates are essential in order to evaluate the risk of functional impairment and establish treatment strategies.

As RNFL defects do not occur in normal eyes, they have a high diagnostic importance to differentiate between normal eyes and eyes with optic nerve damage. RNFL defects are not pathognomonic for glaucomatous optic neuropathy, as they can be found in several other disorders, such as tumours of the pituitary gland, optic disc drusen, diabetic retinopathy, and retinochoroidal scars.

In glaucoma, morphologic changes of the optic disc closely correlate with characteristic patterns of visual loss. Using standard visual field techniques, structural alterations seem to appear before the development of visual field defects. ${ }^{6-16}$ There is also evidence that RNFL loss can be observed before visual field loss. In fact, experimental studies have shown that as many as $25 \%$ to $50 \%$ of RGCs are lost before the decrease in standard automated perimetry (SAP) threshold sensitivity values exceed normal variability and reach statistical significance..$^{14,17-19}$ Thus, RNFL assessment has emerged as an important objective method for diagnosis and monitoring of glaucoma as it develops much earlier than the development of functional loss from field defects.

Optical coherence tomography (OCT) offers a good and objective method for RNFL evaluation. A new generation of spectral-domain OCT (SD-OCT) with a markedly enhanced spatial resolution has been introduced in clinical practice and provides excellent reproducibility of peripapillary RFNL thickness (RNFLT) measurement. Bowd et al. reported statistically significant quantitative differences in RNFLT between ocular hypertension and normal subjects. ${ }^{20}$ Wu et al. reported the sensitivity and specificity of SD-OCT in detecting wedge RNFL defects to be $92 \%$ and $96 \%$, respectively. ${ }^{21}$

In this study, we aimed to estimate the proportion of early POAG patients with normal RNFLT measured with SD-OCT (OCT Spectralis, Heidelberg; Heildeberg, Germany) in Hospital Melaka.

\section{Materials and methods}

Consecutive sampling of 64 patients diagnosed as early POAG and fulfilling the inclusion criteria in the Ophthalmology Clinic in Hospital Melaka were identified. Only one eye from each patient was included. When both eyes were eligible, random sampling by flipping coin was used to determine which eye to include. The sample size was calculated using Epi Info ${ }^{\text {TM }}$ software version 7.1.3.10, 2014. Fifty patients were required to achieve $5 \%$ precision to estimate the proportion of POAG patients with normal RNFL thickness, which is roughly estimated to be 
approximately $3.4 \%$ according to a study by Shen et al. ${ }^{4}$

The inclusion criteria were patients aged $\geq 40$ years old, diagnosed with early POAG, defined as stage 1 or 2 according to Enhanced Glaucoma Staging System (GSS 2) based on mean defect (MD) and loss variance (LV) values. At the time of diagnosis, these patients must have fulfilled the following criteria: characteristic glaucomatous visual field defects which were reproducible in at least two consecutive visits; glaucomatous optic neuropathy such as notching, wedge RNFL defect, splinter haemorrhage, peripapillary beta zone, and vertical cup-disc-ratio (CDR) of 0.7 or more; asymmetrical CDR of 0.2 difference in both eyes; violation of the Inferior, Superior, Nasal, Temporal (ISNT) rule; open angle (Shaffer classification $\geq 3$ ); and intraocular pressure (IOP) $>21 \mathrm{mmHg}$. Other inclusion criteria included spherical refractive error between -5.00 to +5.00 dioptres $(D)$ to ensure the limits were within the Spectralis OCT normative database range of -5.00 to $+7.00 \mathrm{D}$, good SD-OCT signal strength (>15), and clear media for fundus photography. The optic disc photography assessment was done by the principal investigator and confirmed by a consultant ophthalmologist.

The exclusion criteria included: concomitant retinal comorbidities e.g. diabetic retinopathy, retinal vein occlusion; systemic diseases known to affect the RNFLT, e.g. demyelinating disease and pituitary lesions; previous intraocular surgery except for uncomplicated cataract surgery; secondary causes of glaucoma including pseudoexfoliation, pigment dispersion glaucoma, iridocyclitis, and trauma; patients who had had retinal laser procedures including panretinal photocoagulation; and any other causes of optic neuropathy.

RNFLT measurement was conducted by two different operators with at least 2-years' experience in operating the equipment. For each patient, 16 frames were acquired and averaged using the Spectralis OCT (Heidelberg Eye Explorer version 1.8.6.0 and software version 5.7.5.0). The Spectralis OCT provides an Automatic Real-Time (ART) function that utilizes TruTrack ${ }^{\top M}$ image-alignment software, i.e. an eye-tracking system. With ART activated, multiple frames of the same scanning location were performed during the scanning process and images were averaged for speckle noise reduction. The software calculated the average RNFLT for the overall global, four quadrants (superior, inferior, nasal, and temporal), and four additional sectors (i.e. superotemporal, superonasal, inferonasal, and inferotemporal). A signal strength of less than 15 (deemed weak by the manufacturer) was excluded from the analysis. Normal OCT was defined as RNFLT OCT classification showing "within normal limit", while abnormal OCT was defined as RNFLT OCT classification showing "borderline" RNFLT or "outside normal limit".

Automated visual field tests were performed using Octopus 900 perimetry (Haag Streit International, Switzerland). The MD and LV values were plotted on a GSS 2 diagram for glaucoma staging. Only glaucoma stage 1 and 2 (early glaucoma) were enrolled in this study.

Ethical approval was obtained from the Universiti Kebangsaan Malaysia Research 
and Ethics Committee. This study adhered to the tenets of the Declaration of Helsinki and Malaysian Guidelines for Good Clinical Practice. A signed written informed consent was obtained from all patients prior to enrolment.

\section{Results}

\section{Demographic characteristics}

A total of 92 adults diagnosed with early POAG were screened in this study. Of these, 28 were excluded due to poor fundus photograph image $(n=20)$, pre-existing retinopathy, e.g. diabetic retinopathy $(n=7)$, and branch retinal vein occlusion $(n=1)$. A total of 64 patients were finally included in this study. Only one eye of each subject which fulfilled the inclusion criteria was chosen for analysis.

The male-to-female ratio was 1.5:1. There were 27 (42\%) Malays, 30 (47\%) Chinese, and $7(11 \%)$ Indians. The mean age was $64.3 \pm 9.2$ years, with the majority of the patients being in the 60-79 age group.

Among 64 eyes, $57.81 \%$ was found to have normal OCT and $42.19 \%$ to have abnormal OCT classification. There was no difference in terms of age, gender, or ethnicity between those with normal and abnormal OCT grading (Table 1).

Table 1. Demographic characteristics among normal and abnormal OCT groups

\begin{tabular}{|l|l|l|l|}
\hline Variables & $\begin{array}{l}\text { Normal OCT } \\
\boldsymbol{n}=\mathbf{3 7}(\mathbf{5 7 . 8 1 \% )}\end{array}$ & $\begin{array}{l}\text { Abnormal OCT } \\
\boldsymbol{n}=\mathbf{2 7}(\mathbf{4 2 . 1 9 \% )}\end{array}$ & $\boldsymbol{p}$-value \\
\hline $\begin{array}{l}\text { Gender } \\
\text { Male, } \boldsymbol{n}(\%) \\
\text { Female, } \boldsymbol{n} \text { (\%) }\end{array}$ & $23(35.9)$ & $15(23.3)$ & 0.60 ฯ \\
\hline $\begin{array}{l}\text { Ethnicity } \\
\text { Malay, } \boldsymbol{n}(\%) \\
\text { Chinese, } \boldsymbol{n}(\%)\end{array}$ & $12(18.8)$ & \\
Indian, $\boldsymbol{n}(\%)$ & $20(31.3)$ & $12(18.8)$ & $0.17^{\star}$ \\
\hline $\begin{array}{l}\text { Age group, years, } \boldsymbol{n} \\
\text { (\%) }\end{array}$ & $3(4.7)$ & $5(7.8)$ & \\
$\mathbf{4 0 - 4 9}$ & $8(12.5)$ & $2(3.1)$ & \\
$\mathbf{5 0 - 5 9}$ & $12(18.8)$ & $5(7.8)$ & $0.14^{\star}$ \\
$\mathbf{6 0 - 6 9}$ & $13(20.3)$ & $3(23.4)$ & \\
$\mathbf{7 0 - 7 9}$ & $1(1.6)$ & $2(3.1)$ & \\
$\mathbf{8 0 - 8 9}$ & & & \\
\hline $\begin{array}{l}\text { Mean age, } \\
\text { years } \pm \text { SD }\end{array}$ & $64.5 \pm 9.7$ & $64.0 \pm 8.8$ & $0.83 \dagger$ \\
\hline
\end{tabular}

Normal: normal OCT classification; abnormal: borderline or defect OCT classification; OCT: optical coherence tomography; SD: standard deviation

IChi-square; *Fisher's exact test; †Independent t-test 


\section{Ocular characteristics among normal and abnormal OCT grading}

Table 2 shows the ocular characteristics of eyes graded as normal or abnormal (borderline and below normal values) on OCT. The mean RNFLT in eyes graded as normal was thicker $(96.97 \pm 7.54 \mu \mathrm{m})$ than those graded as abnormal $(77.52 \pm 9.06$ $\mu \mathrm{m}, p<0.01)$.

Although the mean IOP at presentation was higher in the abnormal group (29.2 $\pm 5.1 \mathrm{mmHg}$ ) compared to the normal RNFLT group $(27.8 \pm 3.0 \mathrm{mmHg})$, this was not statistically significant ( $p=0.18$, Table 2 ).

The mean duration of POAG also appeared to be longer in the abnormal group ( $25.3 \pm 15.0$ months) compared to the normal group ( $23.7 \pm 12.4$ months), although this again failed to reach statistical significance $(p=0.65)$. The majority of patients had a spherical equivalent between 0.00 and $+1.00 \mathrm{DS}$, with mean spherical dioptres of $1.1 \pm 1.3$ DS and $-0.08 \pm 1.7$ DS in both the normal and abnormal OCT groups, respectively, $p<0.001$.

Table 2. Ocular characteristics among normal and abnormal OCT groups

\begin{tabular}{|c|c|c|c|}
\hline Variables & $\begin{array}{l}\text { Normal OCT } \\
n=37\end{array}$ & $\begin{array}{l}\text { Abnormal OCT } \\
n=27\end{array}$ & $p$-value \\
\hline Mean RNFLT, $\mu \mathrm{m} \pm$ SD & $96.97 \pm 7.54$ & $77.52 \pm 9.06$ & $<0.01 \dagger$ \\
\hline Mean IOP at presentation, $\mathrm{mmHg} \pm \mathrm{SD}$ & $27.8 \pm 3.0$ & $29.2 \pm 5.1$ & 0.189 \\
\hline Mean duration of POAG, month \pm SD & $23.7 \pm 12.4$ & $25.3 \pm 15.0$ & $0.65 \dagger$ \\
\hline $\begin{array}{l}\text { Spherical dioptre group, DS, } n(\%) \\
-3.00 \text { to }-2.01 \\
-2.00 \text { to }-1.01 \\
-1.00 \text { to }-0.01 \\
0.00 \text { to }+1.00 \\
+1.01 \text { to }+2.00 \\
+2.01 \text { to }+3.00\end{array}$ & $\begin{array}{l}3(8.1) \\
1(2.7) \\
6(16.2) \\
16(43.2) \\
9(24.3) \\
2(5.4)\end{array}$ & $\begin{array}{l}5(18.5) \\
5(18.5) \\
2(7.4) \\
7(25.9) \\
6(22.2) \\
2(7.4)\end{array}$ & $0.17^{\star}$ \\
\hline $\begin{array}{l}\text { Refractive group, } n(\%) \\
\text { Hyperopia, } n=42(65.6) \\
\text { Myopia, } n=22(34.4)\end{array}$ & $\begin{array}{l}27(73.0) \\
10(27.0)\end{array}$ & $\begin{array}{l}15(55.6) \\
12(44.4)\end{array}$ & 0.159 \\
\hline Mean spherical dioptres, DS \pm SD & $1.14 \pm 1.30$ & $-0.77 \pm 1.59$ & $<0.01 \dagger$ \\
\hline $\begin{array}{l}\text { Laterality, } n(\%) \\
\text { Right } \\
\text { Left }\end{array}$ & $\begin{array}{l}21(32.8) \\
16(25)\end{array}$ & $\begin{array}{l}13(20.3) \\
14(21.8)\end{array}$ & $0.50 ฯ$ \\
\hline
\end{tabular}

OCT: ocular coherence tomography; RNFLT: retinal nerve fibre layer thickness

ฯChi-square; †Independent t-test; *Fisher's exact test 
A.H.Silim et al.

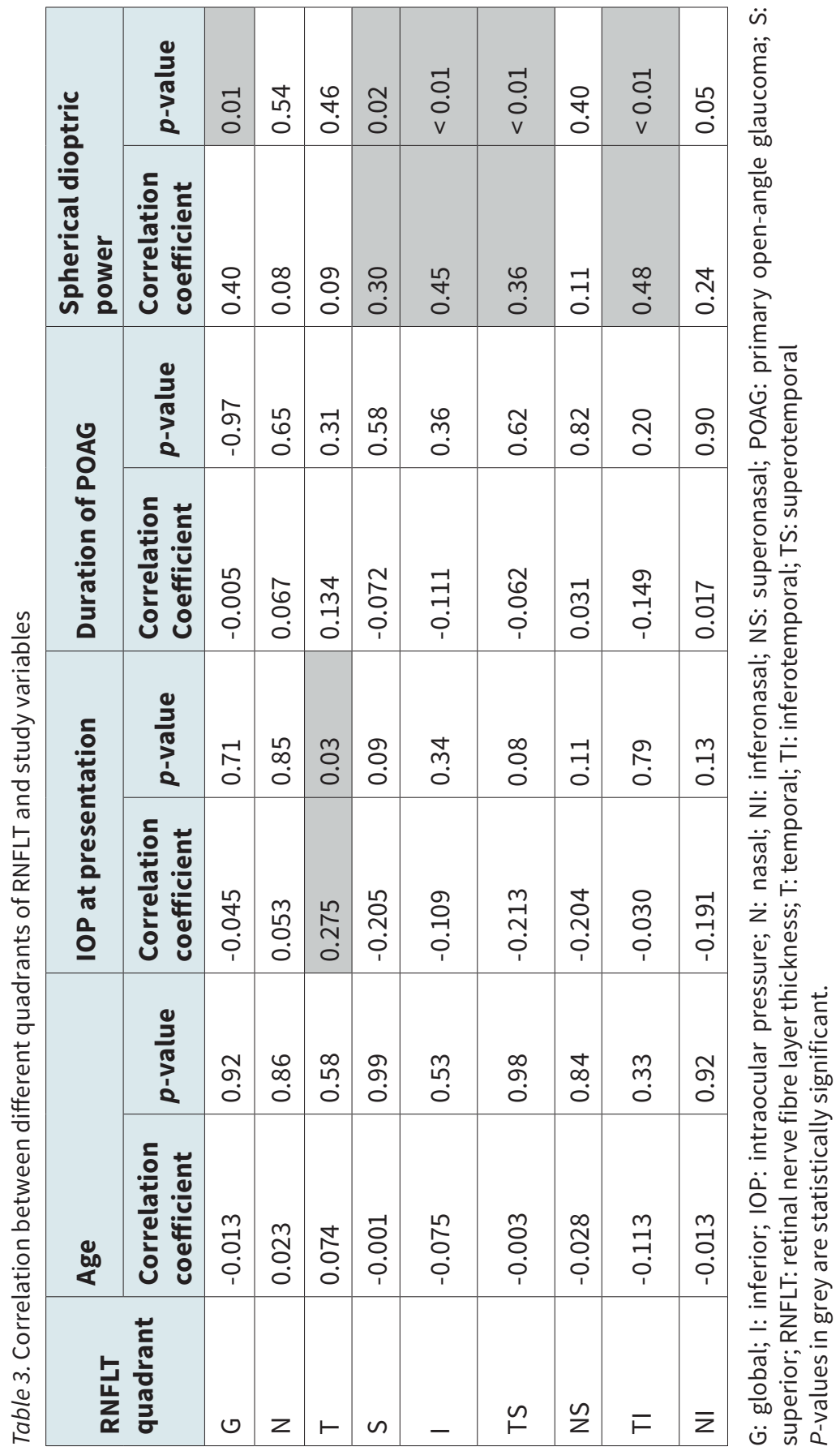




\section{Factors associated with normal and abnormal OCT classification}

We analysed which of the study variables were associated with RNFL thinning in each quadrant (Table 3). In most quadrants, except the nasal and temporal, an increase in age was associated with RNFL thinning; however, this was not statistically significant $(p>0.05)$. The duration of POAG showed an association with RNFL thinning in the majority of quadrants (global, superior, inferior, superotemporal, inferotemporal, and inferonasal); however, it again failed to meet statistical significance. IOP at presentation showed a statistically significant positive weak correlation at the temporal quadrant $(p=0.03)$ and the spherical dioptric power showed significant positive moderate correlation in all except the nasal and temporal quadrants.

\section{Optic disc characteristics among eyes with normal OCT classifications}

Among 37 eyes which were classified as normal OCT, 31 eyes had hard signs of glaucoma such as a notching, peripapillary beta zone, wedge RNFL defect, and/or violation of the ISNT rule (Table 4). The remaining six eyes had variable glaucomatous signs, with one eye showing baring of circumlinear vessel, one showing intrapapillary arterioles narrowing, one with nasalisation of optic disc vessels, and three with bayonetting of the optic disc vessels.

Table 4. RNFLT OCT classification in correlation with the presence of hard glaucomatous signs

\begin{tabular}{|l|l|l|l|}
\hline \multirow{2}{*}{$\begin{array}{l}\text { Hard glaucomatous } \\
\text { signs }\end{array}$} & \multicolumn{2}{|l|}{ RNFLT OCT classification } & \multirow{2}{*}{-value } \\
\cline { 2 - 3 } & $\begin{array}{l}\text { Normal } \\
\boldsymbol{n}=\mathbf{3 7}\end{array}$ & $\begin{array}{l}\text { Abnormal } \\
\boldsymbol{n}=\mathbf{2 7}\end{array}$ & \\
\hline Present, $\boldsymbol{n}(\%)$ & $31(48.4)$ & $23(36.0)$ & \multirow{2}{*}{ (\%) } \\
\hline Absent, $\boldsymbol{n}(\%)$ & $6(9.3)$ & $4(6.3)$ & \\
\hline
\end{tabular}

OCT: ocular coherence tomography; RNFLT: retinal never fibre layer thickness

*Fisher's exact test

Table 5. Distribution of notching according to quadrants and respective RNFLT OCT grading

\begin{tabular}{|l|l|l|l|}
\hline Notching & \multicolumn{2}{|l|}{ RNFLT OCT grading } & Defect \\
\hline Location, $\boldsymbol{n}(\%)$ & Normal & Borderline & $2(50.0)$ \\
\hline TS, $n=4(100 \%)$ & $2(50.0)$ & $0(0)$ & $0(0)$ \\
\hline NS, $n=1(100 \%)$ & $1(100)$ & $0(0)$ & $6(66.7)$ \\
\hline TI, $n=9(100 \%)$ & $2(22.2)$ & $1(11.1)$ & $8(57.2)$ \\
\hline $\begin{array}{l}\text { TOTAL, } \boldsymbol{n}=\mathbf{1 4} \\
\text { (100\%) }\end{array}$ & $5(35.7)$ & $1(7.1)$ & \\
\hline
\end{tabular}

NS: superonasal quadrant; OCT: ocular coherence tomography; RNFLT: retinal never fibre layer thickness; TI: inferotemporal quadrant; TS: superotemporal quadrant 
Nine (64.3\%) eyes with notching had corresponding RNFL thinning (borderline/ defect of RNFLT) in the same quadrant. Five (35.7\%) eyes had a notch but no corresponding abnormal OCT in the same quadrant (Table 5).

\section{Association between peripapillary beta zone and its respective RNFL OCT grading}

Of 64 eyes, $3(4.7 \%)$ eyes had peripapillary beta zone observed in their optic disc stereoscopic photograph, of which only 1 (33.3\%) eye had a corresponding RNFL defect. Two peripapillary beta zones were seen in superotemporal quadrants and one peripapillary beta zone was observed in the inferior quadrant.

\section{Association between wedge RNFL defects and its respective RNFL OCT grad- ing}

Out of 64 sample eyes, 27 wedge RNFL defects were observed in their optic disc stereoscopic photography. Eleven wedge RNFL defects were seen in the superotemporal and inferotemporal quadrants, four in the superonasal quadrant, and one in the nasal quadrant. Six of $11(54.5 \%)$ and 8 of $11(72.7 \%)$ defects seen in the superotemporal and inferotemporal quadrants, respectively, were associated with corresponding RNFL thinning on OCT, whereas none of the wedge defects seen in the superonasal and nasal quadrants showed RNFL thinning on OCT. Similar to notching, wedge RNFL defects caused significant RNFL thinning in 14 of 27 (51.9\%) eyes (Table 6).

Table 6. Distribution of wedge RNFL defects according to quadrants and respective OCT RNFLT grading

\begin{tabular}{|l|l|l|l|}
\hline $\begin{array}{l}\text { Location of wedge } \\
\text { RNFL defect } \boldsymbol{n = 2 7}\end{array}$ & \multicolumn{4}{|l|}{ RNFLT OCT grading } \\
\hline Location, $\boldsymbol{n}$ & Normal & Borderline & Defect \\
\hline TS, $n=11(\%)$ & $5(45.5)$ & $0(0)$ & $6(54.5)$ \\
\hline NS, $n=4(\%)$ & $4(100)$ & $0(0)$ & $0(0)$ \\
\hline TI, $n=11(\%)$ & $3(27.3)$ & $3(27.3)$ & $5(45.4)$ \\
\hline N, $n=1(\%)$ & $1(100)$ & $0(0)$ & $0(0)$ \\
\hline Total, $n=27(\%)$ & $13(48.1)$ & $3(11.1)$ & $11(40.8)$ \\
\hline
\end{tabular}

$\mathrm{N}$ : nasal quadrant; NS: superonasal quadrant; OCT: ocular coherence tomography; RNFLT: retinal never fibre layer thickness; TI: inferotemporal quadrant; TS: superotemporal quadrant 
Table 7. ISNT rule in correlation with RNFLT OCT classification

\begin{tabular}{|l|l|l|l|}
\hline ISNT Rule & $\begin{array}{l}\text { Normal OCT } \\
\boldsymbol{n}=\mathbf{3 7}\end{array}$ & $\begin{array}{l}\text { Abnormal OCT } \\
\boldsymbol{n}=\mathbf{2 7}\end{array}$ & $\boldsymbol{p}$-value \\
\hline $\begin{array}{l}\text { Obey, } \\
n=22(34.38 \%)\end{array}$ & $10(45.45 \%)$ & $12(54.55 \%)$ & $0.15^{\#}$ \\
\hline $\begin{array}{l}\text { Disobey, } \\
n=42(65.62 \%)\end{array}$ & $27(64.29 \%)$ & $15(34.71 \%)$ & \\
\hline
\end{tabular}

OCT: ocular coherence tomography; RNFLT: retinal never fibre layer thickness \#Pearson correlation

\section{ISNT rule and RNFL OCT classification}

Table 7 shows that violation of the ISNT rule is not associated with RNFL thinning ( $p=0.152)$. Among 64 eyes, $22(34.38 \%)$ eyes did not violate the ISNT rule, of which $45.45 \%$ had normal OCT and $54.55 \%$ had abnormal OCT, whereas 42 eyes $(65.62 \%)$ violated the ISNT rule, of which $64.29 \%$ had normal OCT and $34.71 \%$ had abnormal OCT.

\section{Discussion}

This study recruited a total of 64 early POAG patients with one eye per patient taken as sample. The OCT findings were normal in $57.8 \%$ and abnormal in $42.2 \%$ of the patients. This is in keeping with previous findings by Rao et al., who reported the sensitivity of SD-OCT in detecting average RNFL thinning in early glaucoma patients was $37.4 \%$ at a fixed $95 \%$ specificity. ${ }^{22}$ Of note, the Spectralis OCT uses its own normative database, which is based on the Caucasian population. Many studies have found variations in RNFLT among races and ethnicities. Budenz et al. reported that the Hispanic and Asian ethnicities had a significantly thicker mean RNFL compared to those of European origin. ${ }^{23}$ Alasil et al. also reported that the mean RNFLT measured by SD-OCT in Caucasians was significantly lower (96 \pm 9.2 $\mu \mathrm{m})$ than those of Hispanic $(102.9 \pm 11 \mu \mathrm{m})$ or Asian descent $(100.7 \pm 8.5 \mu \mathrm{m}) .{ }^{24} \mathrm{Th}$ is may likely explain why $57.81 \%$ of early POAG patients were classified as normal by the Spectralis OCT in our study.

In this study, patients were divided into those with normal and abnormal RNFLT (borderline and below normal values). In both groups, the mean age was comparable, with the majority of patients falling between 60-69 years of age. There was no significant difference in gender or ethnicity between the groups. In two population-based studies done in Singapore, POAG was found to be the predominant form in more than $40 \%$ of Malay and Chinese patients. ${ }^{3,4}$ Although the mean IOP at presentation was higher and the duration of POAG was longer in 
the abnormal than in the normal OCT group in our study, we found there was no statistical significance for these variables.

POAG is a disease involving progressive optic neuropathy. Despite treatment, there will be gradual progression of the disease even when the modifiable risk factor, which is IOP, is well controlled. Thus, the longer the duration of POAG, the more neuropathy is expected to progress, which could explain our findings. Given the present study included only early-stage POAG, there was not much difference in POAG duration between both groups.

We found a significant difference between spherical dioptres in both groups as well. The majority of eyes in both groups were between 0.00 and +1.00 in spherical dioptres. However, in the abnormal OCT group, the mean spherical equivalent was leaning towards myopia. This finding is in agreement with previous studies that found RNFLT is thinner in myopic eyes. ${ }^{25-26}$

Among all variables, RNFLT in the global, temporal, superior, inferior, superotemporal, and inferotemporal quadrants showed significant correlation with the study variables. We found that an increase in spherical dioptres was moderately correlated with an increase in RNFL in most quadrants except the nasal, temporal, superonasal, and inferonasal. The significance of myopia and RNFLT has been reported in many studies. ${ }^{23,25-27}$. Budenz et al. found that RNFLT was related significantly to both axial length and refractive error. ${ }^{23}$ The Blue Mountains Eye Study showed that glaucoma was present in $4.2 \%$ of eyes with low myopia and $4.4 \%$ of eyes with moderate-to-high myopia compared to $1.5 \%$ of eyes without myopia ${ }^{29}$. This study confirmed a strong relationship between myopia and glaucoma, consistent with our findings.

We also found a weak positive correlation between IOP at presentation and RNFLT in the temporal quadrant. The OCT readings in this study were taken after the patients were initiated on IOP-lowering medications and the IOP was well controlled. We postulate that higher IOP at presentation was associated with thicker RNFL in the temporal quadrant because, generally, patients with higher IOP are likely to be treated more aggressively than those with lower IOP at presentation. This will affect, in general terms, the progression of glaucoma and further RNFL thinning. Hence, after a period of time, those with high IOP at presentation had less glaucoma progression and showed relatively "thicker" RNFL than those with lower IOP at presentation.

Correlation between quadrants and study variables also found that RNFLT is correlated with increasing age in the majority of quadrants except the nasal and temporal. However, this correlation failed to reach statistical significance. This was probably due to the fact that the study had a small sample and was not well distributed among age groups, as we used consecutive sampling. However, this is consistent with a previous study on the effects of aging and RNFL thinning. ${ }^{24}$ RNFLT does not show a significant decrease with aging in the nasal and temporal quadrants among the normal population. ${ }^{23}$

Even in the presence of glaucomatous hard signs such as notching and wedge 
RNFL defects on optic disc photographs, we found that the Spectralis OCT did not classify all these cases as abnormal OCT in their respective quadrants in early POAG. Fourteen eyes were observed to have notching, of which the majority (nine eyes) was classified as abnormal OCT of its respective quadrant, while the remaining five were normal. Twenty-seven wedge RNFL defect areas were seen, and 14 were classified as abnormal. Previous studies have shown the sensitivity of OCT to detect wedge RNFL defects to be between $80 \%$ to $92 \%$, with a specificity between $92 \%$ and $94 \% .{ }^{20,30}$ In this study, we used red-free optic disc photography instead of blue-reflectance RNFL photography by confocal scanning laser ophthalmoscopy, which has been proven to be a better way to visualize RNFL thinning. ${ }^{31,32}$ Precise visualization of the RNFL from red-free photography also requires a skilled imager, good pupil dilation, relatively clear media, and high-contrast view, which makes examination difficult in patients with cataract and pigmented fundi.

Although we reached a sample size large enough to achieve the targeted power of the study, the number of eyes with glaucomatous features in each cell was small and this reduced meaningful associations. Increasing the sample size would help identify significant associations between individual hard signs of glaucomatous disc changes and RNFLT.

\section{Conclusion}

We conclude that OCT should not be the only tool relied upon to diagnose glaucoma, especially in the early stages. This is supported by the fact that, in our study, more than half of early POAG patients had normal RNFL thickness, possibly attributable to ethnic differences when using normative values from a Caucasian population as reference. Other diagnostic tools such as the Humphrey Visual Field Analyzer and clinical optic disc assessment should be employed as well.

\section{Acknowledgements}

This study was registered with the Medical Research \& Ethics Committee, Ministry of Health Malaysia under registration research number NMRR-14-1909-22968 (IIR) and Research Ethics Committee of Universiti Kebangsaan Malaysia under research code FF-2014-435. 


\section{References}

1. Quigley HA, Broman AT. The number of people with glaucoma worldwide in 2010 and 2020. Br J Ophthalmol. 2006;90(3):262-267. doi:10.1136/bjo.2005.081224

2. Hattenhauer MG, Johnson $\mathrm{DH}$, Ing HH, et al. The probability of blindness from open-angle glaucoma. Ophthalmology. 1998;105(11):2099-2104. doi:10.1016/S0161-6420(98)91133-2

3. Foster PJ, Oen FTS, Machin D, et al. The Prevalence of Glaucoma in Chinese Residents of Singapore: A Cross-Sectional Population Survey of the Tanjong Pagar District. Arch Ophthalmol. 2000;118(8):11051111. doi:10.1001/archopht.118.8.1105

4. Shen SY, Wong TY, Foster PJ, et al. The Prevalence and Types of Glaucoma in Malay People: The Singapore Malay Eye Study. Invest Ophthalmol Vis Sci. 2008;49(9):3846-3851. doi:10.1167/iovs.08-1759

5. Zainal M, Ismail SM, Ropilah AR, et al. Prevalence of blindness and low vision in Malaysian population: results from the National Eye Survey 1996. Br J Ophthalmol. 2002;86(9):951-956. doi:10.1136/ bjo.86.9.951

6. Hood DC, Kardon RH. A framework for comparing structural and functional measures of glaucomatous damage. Prog Retin Eye Res. 2007;26(6):688-710. doi:10.1016/j.preteyeres.2007.08.001

7. Medeiros FA, Alencar LM, Zangwill LM, Bowd C, Sample PA, Weinreb RN. Prediction of functional loss in glaucoma from progressive optic disc damage. Arch Ophthalmol. 2009;127(10):1250-1256. doi:10.1001/archophthalmol.2009.276

8. Harwerth RS, Carter-Dawson L, Smith EL, Barnes G, Holt WF, Crawford MLJ. Neural losses correlated with visual losses in clinical perimetry. Invest Ophthalmol Vis Sci. 2004;45(9):3152-3160. doi:10.1167/ iovs.04-0227

9. Kass MA, Heuer DK, Higginbotham EJ, et al. The Ocular Hypertension Treatment Study: a randomized trial determines that topical ocular hypotensive medication delays or prevents the onset of primary open-angle glaucoma. Arch Ophthalmol. 2002;120(6):701-713; discussion 829-830.

10. Wollstein G, Schuman JS, Price LL, et al. Optical coherence tomography longitudinal evaluation of retinal nerve fiber layer thickness in glaucoma. Arch Ophthalmol. 2005;123(4):464-470. doi:10.1001/ archopht.123.4.464

11. Strouthidis NG, Scott A, Peter NM, Garway-Heath DF. Optic disc and visual field progression in ocular hypertensive subjects: detection rates, specificity, and agreement. Invest Ophthalmol Vis Sci. 2006;47(7):2904-2910. doi:10.1167/iovs.05-1584

12. Leung CK, Cheung CYL, Weinreb RN, et al. Evaluation of retinal nerve fiber layer progression in glaucoma: a study on optical coherence tomography guided progression analysis. Invest Ophthalmol Vis Sci. 2010;51(1):217-222. doi:10.1167/iovs.09-3468

13. Medeiros FA, Alencar LM, Zangwill LM, Sample PA, Weinreb RN. The Relationship between intraocular pressure and progressive retinal nerve fiber layer loss in glaucoma. Ophthalmology. 2009;116(6):1125-1133.e1-3. doi:10.1016/j.ophtha.2008.12.062

14. Quigley HA, Dunkelberger GR, Green WR. Retinal Ganglion Cell Atrophy Correlated With Automated Perimetry in Human Eyes With Glaucoma. Am J Ophthalmol. 1989;107(5):453-464. doi:10.1016/00029394(89)90488-1

15. Thoss F. Visual threshold estimation and its relation to the question: Fechner-law or Stevens-power function. Acta Neurobiol Exp (Warsz). 1986;46(5-6):303-310. 
16. Garway-Heath DF, Holder GE, Fitzke FW, Hitchings RA. Relationship between electrophysiological, psychophysical, and anatomical measurements in glaucoma. Invest Ophthalmol Vis Sci. 2002;43(7):2213-2220.

17. Harwerth RS, Wheat JL, Fredette MJ, Anderson DR. Linking structure and function in glaucoma. Prog Retin Eye Res. 2010;29(4):249-271. doi:10.1016/j.preteyeres.2010.02.001

18. Airaksinen PJ, Drance SM, Douglas GR, Schulzer M, Wijsman K. Visual Field and Retinal Nerve Fiber Layer Comparisons in Glaucoma. Arch Ophthalmol. 1985 Feb 1;103(2):205-7.

19. Flammer J, Drance SM, Augustiny L, Funkhouser A. Quantification of glaucomatous visual field defects with automated perimetry. Invest Ophthalmol Vis Sci. 1985 Feb 1;26(2):176-81.

20. Bowd C, Weinreb RN, Williams JM, Zangwill LM. The Retinal Nerve Fiber Layer Thickness in Ocular Hypertensive, Normal, and Glaucomatous Eyes With Optical Coherence Tomography. Arch Ophthalmol. 2000;118(1):22-26. doi:10.1001/archopht.118.1.22

21. Agreement Between Spectral Domain Optical Coherence Tomography and Retinal Nerve Fiber Layer Photography in Chinese | Ovid. https://oce.ovid.com/article/00061198-201204000-00004/HTML. Accessed May 27, 2019.

22. Rao HL, Babu JG, Addepalli UK, Senthil S, Garudadri CS. Retinal nerve fiber layer and macular inner retina measurements by spectral domain optical coherence tomograph in Indian eyes with early glaucoma. Eye. 2012;26(1):133-139. doi:10.1038/eye.2011.277

23. Budenz DL, Anderson DR, Varma R, et al. Determinants of normal retinal nerve fiber layer thickness measured by Stratus OCT. Ophthalmology. 2007;114(6):1046-1052. doi:10.1016/j.ophtha.2006.08.046

24. Alasil T, Wang K, Keane PA, et al. Analysis of normal retinal nerve fiber layer thickness by age, sex, and race using spectral domain optical coherence tomography. J Glaucoma. 2013;22(7):532-541. doi:10.1097/IJG.0b013e318255bb4a

25. Knight OJ, Girkin CA, Budenz DL, Durbin MK, Feuer WJ, Group for the CONDS. Effect of Race, Age, and Axial Length on Optic Nerve Head Parameters and Retinal Nerve Fiber Layer Thickness Measured by Cirrus HD-OCT. Arch Ophthalmol. 2012;130(3):312-318. doi:10.1001/archopthalmol.2011.1576

26. Kashiwagi K, Tamura M, Abe K, Kogure S, Tsukahara S. The influence of age, gender, refractive error, and optic disc size on the optic disc configuration in Japanese normal eyes. Acta Ophthalmol Scand. 2000;78(2):200-203. doi:10.1034/j.1600-0420.2000.078002200.x

27. Leung CK-S, Mohamed S, Leung KS, et al. Retinal Nerve Fiber Layer Measurements in Myopia: An Optical Coherence Tomography Study. Invest Ophthalmol Vis Sci. 2006;47(12):5171-5176. doi:10.1167/iovs.06-0545

28. Melo GB, Libera RD, Barbosa AS, Pereira LMG, Doi LM, Melo LAS. Comparison of Optic Disk and Retinal Nerve Fiber Layer Thickness in Nonglaucomatous and Glaucomatous Patients With High Myopia. Am J Ophthalmol. 2006;142(5):858-860. doi:10.1016/j.ajo.2006.05.022

29. Mitchell P, Hourihan F, Sandbach J, Jin Wang J. The relationship between glaucoma and myopia: The blue mountains eye study. Ophthalmology. 1999;106(10):2010-2015. doi:10.1016/S01616420(99)90416-5

30. Kim NR, Lee ES, Seong GJ, Choi EH, Hong S, Kim CY. Spectral-Domain Optical Coherence Tomography for Detection of Localized Retinal Nerve Fiber Layer Defects in Patients With Open-Angle Glaucoma. Arch Ophthalmol. 2010;128(9):1121-1128. doi:10.1001/archophthalmol.2010.204 
31. Hong S, Ahn H, Ha SJ, Yeom HY, Seong GJ, Hong YJ. Early Glaucoma Detection Using the Humphrey Matrix Perimeter, GDx VCC, Stratus OCT, and Retinal Nerve Fiber Layer Photography. Ophthalmology. 2007;114(2):210-215. doi:10.1016/j.ophtha.2006.09.021

32. Hong S, Moon JW, Ha SJ, Kim CY, Seong GJ, Hong YJ. Evaluation of a New Scoring System for Retinal Nerve Fiber Layer Photography Using HRA1 in 964 Eyes. Korean J Ophthalmol. 2007;21(4):216-221. doi:10.3341/kjo.2007.21.4.216 